\title{
Simulating the mid-Holocene in PMIP
}

\author{
Chris Brierley ${ }^{1}$ and Qiong Zhang ${ }^{2}$
}

\begin{abstract}
The midHolocene experiment has been a target period for PMIP activity since the beginning. It has gone through four different iterations in the past 30 years. Over 60 models, of various levels of complexity and resolution, have been used for the midHolocene experiment-contributed from around 20 different modeling groups. They all capture a similar large-scale response, but with a level of detail and understanding that increases with every PMIP phase.
\end{abstract}

\section{Experimental design}

Before describing the design, it is probably worth explaining why the mid-Holocene was chosen as a target period. The ideal period to simulate is one that has a large forced climate change (so a high signalto-noise ratio), as well as plentiful accurate paleoclimate reconstructions with which to compare the model results. Reconstructions suggest that 6,000 years ago, the tail-end of the African Humid Period, was the warmest portion of the Holocene (COHMAP Members 1988). Yet subsequent transient simulations do not show a warming peak: a "Holocene conundrum" that is not fully resolved (Bader et al. 2020). A different time period might have been chosen today, but the wealth of research focused around 6,000 kyr BP since this period was selected by PMIP means there is little point in deviating now.

The midHolocene experiment has kept the same orbital settings since its inception, although other aspects of the design have evolved over the years (Joussaume and Taylor 1995; Otto-Bliesner et al. 2017). The main forcing is an alteration in the precession by roughly a right angle- 6,000 years ago the Earth was closest to the sun in Northern Hemisphere (NH) autumn, not during $\mathrm{NH}$ winter as is the case today. Determining a consistent way to apply this change was tricky, because of the way orbits, incoming insolation, and internal model calendars are embedded in model radiative codes. The implications of internal calendars being hardwired in models' data output routines are still being felt and need to be considered in analyses (Bartlein and Shafer 2019). The obliquity and eccentricity are also altered. Other settings, such as land cover and atmospheric composition, follow the standard control simulation (i.e. perpetual 1850 CE conditions, except for PMIP1 which used an atmosphere-only set up). For the first time, PMIP4 applied observed greenhouse gas conditions for 6,000 kyr BP, mainly a drop in $\mathrm{CO}_{2}$ levels of $25 \mathrm{ppm}$ from 284 $\mathrm{ppm}$ in the pre-industrial (Otto-Bliesner et al. 2017).

\section{Uptake and reach}

More models have performed midHolocene simulations than any other PMIP run-mainly due to the relative ease of prescribing its boundary conditions. The headline papers of the four different PMIP phases include a total of 60 models (Joussaume et al. 1999; Braconnot et al. 2007; Braconnot et al. 2012;
Brierley et al. 2020); further, models have performed this standard experiment outside of those publications. There has been a steady increase in both model resolution and complexity throughout the four phases (Braconnot et al. this issue). The simulations have gained models of the ocean, sea ice, and increasingly interactive vegetation. This latter component helps with the expansion of the North African monsoon into the "green Sahara", but models still do not fully capture this transition (Brierley et al. 2020).

There have been a large number of researchers involved with the PMIP midHolocene simulations, with 77 different authors on the four initial description papers alone. Many publications have been written (nearly 2,000 that include PMIP and mid-Holocene in their keywords), and this number will only increase with time. The midHolocene experiment has also been discussed in all IPCC reports since AR3 (Kageyama et al. this issue, p. 68).

\section{Findings}

The midHolocene experiment reassuringly demonstrates that climate models show a consistent response to changes in radiative forcings that fits well with our theoretical understanding of the Earth system. The shift in the seasonal distribution of incoming solar energy leads to seasonal temperature changes that are amplified by continentality.
These temperature changes lead to variations in the thermal equator and hence the seasonal march of the intertropical convergence zone (ITCZ) and the associated precipitation patterns. These fundamental features of mid-Holocene climate are found in paleoclimate reconstructions and have been present in results from simulations since PMIP1 (Joussaume et al. 1999).

The creation of ensembles of simulations focused at 6,000 years ago has spurred concerted efforts within the paleoclimate data community. It has motivated researchers to include the period when designing the creation of individual reconstructions. There is a dimensional difference between model simulations, which have global spatial coverage for a limited time, and paleoclimate reconstructions, which track time variations at a fixed location. Data compilations from a time-slice centered on the mid-Holocene have been created to overcome this (Bartlein and Webb, this issue). These compilations also permit the quantitative benchmarking of the midHolocene simulations (Harrison et al. 2014). Although this remains challenging to undertake, results have contributed to IPCC assessments of models (Kageyama et al. this issue, p. 68).

Paleoclimate compilations highlight the dramatic changes in hydroclimate that

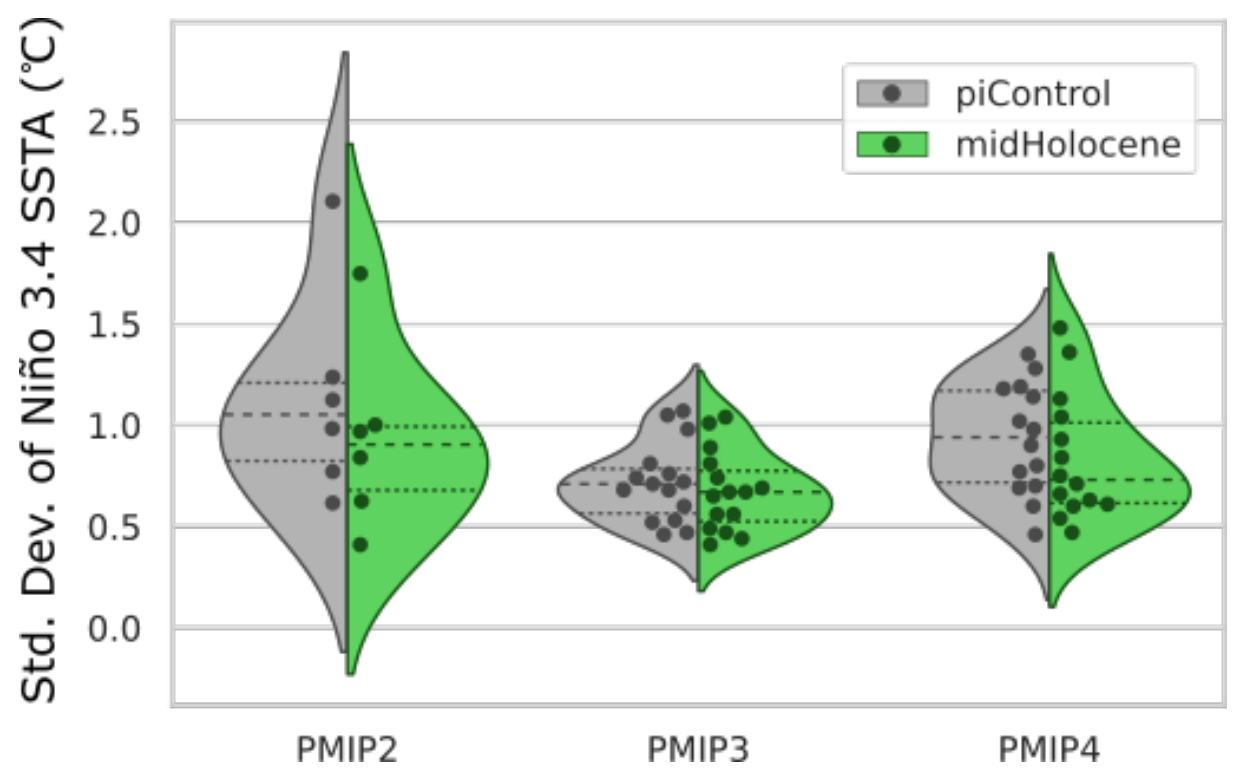

Figure 1: ENSO activity, as measured by the standard deviation of monthly sea surface temperature anomalies averaged over the "Niño 3.4" region of the equatorial Pacific, in PMIP2 (An and Choi 2014), PMIP3, and PMIP4 (Brown et al. 2020). 


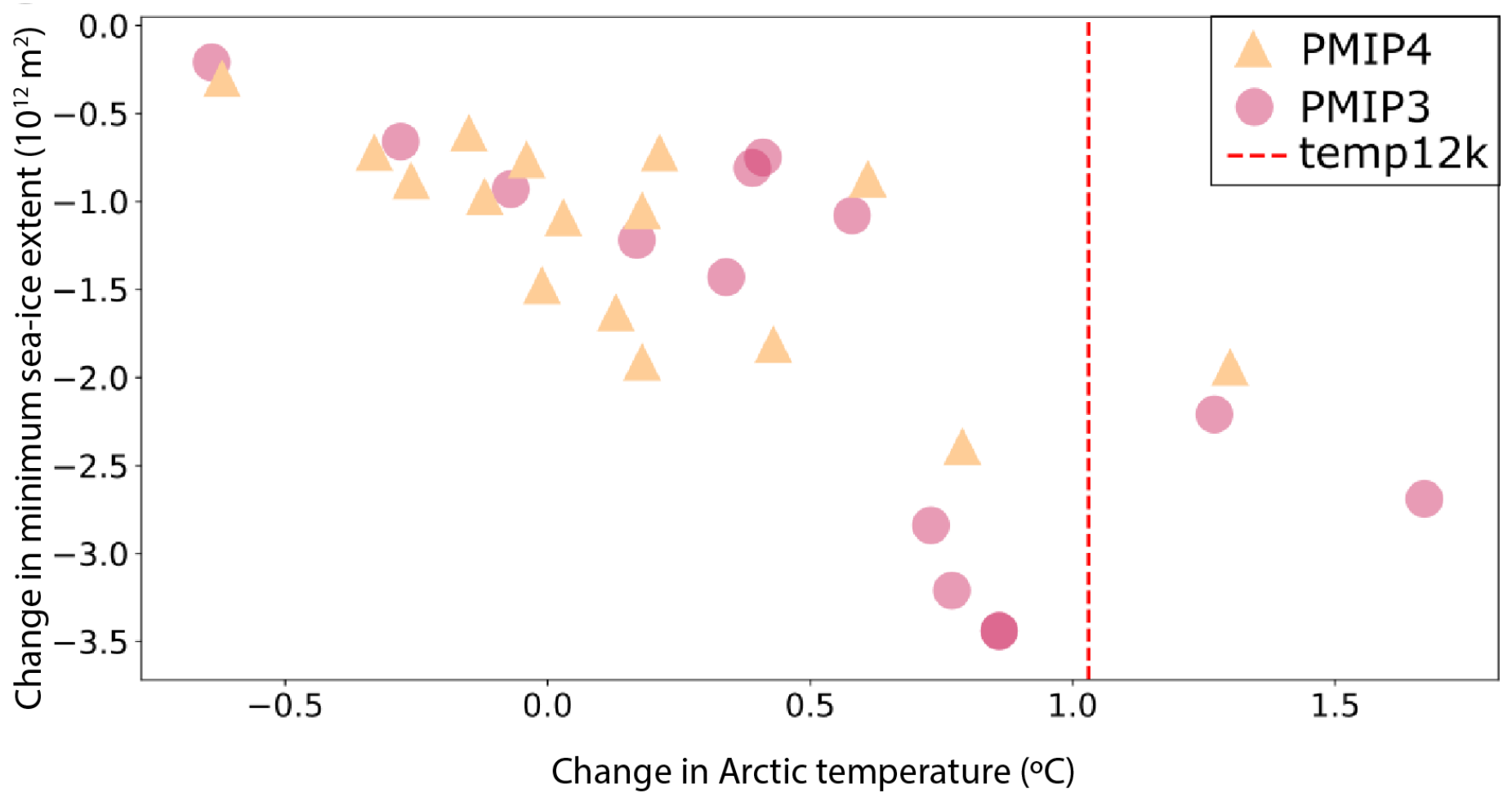

Figure 2: The relationship between the change in annual mean Arctic temperatures and the Northern Hemisphere minimum sea-ice extent (Brierley et al. 2020). The median of the annual mean temperature changes over the Arctic reconstructed by the Temperature 12k compilation of Kaufman et al. (2020) is shown as a vertical line.

happened during the mid-Holocene in the subtropics. The African Humid Period, colloquially called the "green Sahara", is associated with a dramatic poleward extension of the West African monsoon and wetter conditions across northern Africa. It started prior to the Holocene and had already ended in some locations by 6,000 years ago (Shanahan et al. 2015). This has been a focus of analysis since the first phase of PMIP (Joussaume and Taylor, this issue; Braconnot et al. this issue).

Around the time of the completion of PMIP1 came the discovery that ENSO variability in reconstructions was weaker during the midHolocene (Rodbell et al. 1999). This opened a new possible research avenue (Rehfeld and Brown, this issue), which has now become a major focus of activity around the midHolocene simulations (Zheng et al. 2008; An and Choi 2014; Brown et al. 2020). Models show reduced ENSO activity in response to the mid-Holocene orbital changes. Over the three PMIP phases with coupled models (PMIP2-PMIP4), the ENSO reduction has become more consistent (Fig. 1). Yet the mechanisms for this response are not entirely clear, complicating our ability to pull that success forward into more confident projections of future ENSO changes.

Outside of the tropics, the results of the midHolocene experiment show large seasonal temperature variations. One consequence of this is a reduction in summer sea-ice extent in the Arctic (Fig. 2). Non-linear feedbacks of both this and the increase in winter sea ice result in increasing uncertainty regarding the annual mean temperature change in the Arctic. There is however a robust relationship between Arctic temperature change and sea-ice extent in the models, which seems more consistent in PMIP4 compared to earlier phases.

\section{Outlook}

The ensemble of PMIP4 midHolocene simulations has only recently been completed, and publications documenting the individual constituent simulations are still emerging. We envisage that the midHolocene simulations will be the focus of many multi-model analyses in the next couple of years. The PMIP structure, part of a global modeling effort that includes future scenarios, permits these analyses to readily include multiple experiments. The combination with the lig127k experiment (Otto-Bliesner et al. this issue) allows the robustness and magnitude of orbital forcing to be assessed. The combination with warming experiments, be they either idealized simulations or future scenarios, allows the lessons from the midHolocene to be quantitatively connected to the associated changes anticipated for this century. Personally, we would love to see greater use of the midHolocene simulations amongst the wider climate modeling community, for example by working together with the global monsoon MIP or sea-ice MIP efforts.

Finally, it is worth asking whether the next generation of coupled models should also run midHolocene experiments. We are now in the position where transient Holocene simulations with GCMs are feasible (OttoBliesner et al. 2017). These are more intellectually stimulating, remove some problems with data-model comparisons, and perhaps are more helpful for future scenarios (which themselves are mostly transient). However, Holocene transients cannot be made with the shiniest, most computationally expensive models. Over the next few years of analyses on the PMIP4 midHolocene simulations, we must investigate whether the effort and resources needed to use the state-of-theart models are justifiable, for example, by exploring the experiment's potential to evaluate interactive vegetation, dust, and carbon cycle models.

\section{AFFILIATIONS}

'Department of Geography, University College London, UK

${ }^{2}$ Department of Physical Geography, Stockholm University, Sweden

\section{CONTACT}

Chris Brierley: c.brierley@ucl.ac.uk

\section{REFERENCES}

An S-I, Choi J (2014) Clim Dyn 43: 957-970 Bader J et al. (2020) Nat Commun 11: 4726 Bartlein PJ, Shafer SL (2019) Geosci Model Dev 12: 3889-3913

Braconnot P et al. (2007) Clim Past 3: 261-277 Braconnot P et al. (2012) Nat Clim Chang 2: 417-424 Brierley CM et al. (2020) Clim Past 16: 1847-1872 Brown JR et al. (2020) Clim Past 16: 1777-1805 COHMAP Members (1988) Science 241: 1043-1052 Harrison SP et al. (2014) Clim Dyn 43: 671-688 Joussaume S, Taylor KE (1995) Status of the paleoclimate modeling intercomparison project, Proceedings of the first international AMIP scientific conference, WCRP Report, 425-430

Joussaume S et al. (1999) Geophys Res Lett 26: 859-862 Kaufman D et al. (2020) Sci Data 7: 201

Otto-Bliesner BL et al. (2017) Geosci Model Dev 10: 3979-4003

Rodbell DT et al. (1999) Science 283: 516-520

Shanahan T et al. (2015) Nat Geosci 8: 140-144

Zheng W et al. (2008) Clim Dyn 30: 745-762 